\title{
EASTER CELEBRATIONS WITH A \\ DIFFERENCE: A CRITICAL STUDY OF \\ THE JOHANE MASOWE CHISHANU YENYENYEDZI APPROACH TO THE EVENT
}

\author{
Phillip Musoni \\ University of Pretoria \\ pmusoni@gmail.com
}

\section{Paul Gundani}

University of South Africa

gundaph@unisa.ac.za

\section{ABSTRACT}

The celebration of Easter has become a universal event within the Christian liturgical calendar and aims to commemorate the passion, death, burial and resurrection of Jesus Christ. Messages on the passion, death, burial and resurrection of Jesus Christ are vigorously proclaimed throughout the holy week, which usually begins on a holy Thursday ending on a resurrection Sunday (Easter Sunday). Some Churches will even dramatise the events that led to the death of Jesus Christ and how He was crucified on the cross. Apparently, the purpose of these ritual re-enactments is to capture the minds of the congregants on how their Saviour suffered and eventually died on the cross to bring salvation to humanity. Invariably, on resurrection Sunday, the services will end with a ritual of Holy Communion. However, while other Christian denominations commemorate the death, burial and resurrection of Jesus Christ at Easter, we have noted that the Johane Masowe Chishanu yeNyenyedzi Church celebrates 'Easter' with a difference. For them 'Easter' is the time to remember the 'Fathers of the Faith', i.e. the messianic leaders whom God raised to give leadership and guidance to the church. Every Easter, the Johane Masowe Chishanu yeNyenyedzi Religious Movement commemorates deliverance from evil spirits, which was made

\section{UNISA}


possible through the charismatic leadership of Shonhiwa Masedza (Johane), founder of the original 'Church'; Mudyiwa Dzangara (Emanuere), second from Johane; and Sanders Nhamoyebonde (Sanders/Nyenyedzi), third from Johane. In the view of the Church adherents, Jesus Christ was sent by God to deliver people of mhiri yegungwa (overseas), i.e., the whites and the Jews, whilst Masedza, Mudyiwa and Nhamoyebonde were sent by God to deliver Africans. It is against this background that this study seeks to delve deeper into this religious movement's unique ways of celebrating the memory of their spiritual leaders during Easter commemorations. Interviews and participant observation are the key tools used for data collection, since this movement under study has no written documents.

Keywords: Africans, Easter, Masowe yeNyenyedzi Religious Movement, messianic leaders, Mhiri yegungwa (overseas); Holy Communion

\section{Introduction}

The emergence of African Indigenous Churches (AICs) on the continent of Africa has been an occurrence so rapid and extensive that it has forced church historians to focus on the key emergence of African Christianity. While earlier studies on Christianity in Africa focused on the roles of European missionaries planting churches, church historians today tend to focus on the roles of African converts, interpreting Christianity into their thought-forms (Kurewa 1975, 36) and establishing new Christian movements that are uniquely African as well as authentically Christian (Sundkler 2000, 16). Within the passages of a long history of Christianity in Africa, the term 'African Christianity' emerged around the 1950s-1960s. This term gained wide currency after Pope John Paul VI's visit to Uganda in 1969. Pope John Paul VI concluded his presentation in the following words: 'From this point of view, certain pluralism is not only reasonable, but desirable...And in this sense you may, and you must have "African Christianity"' (Shorter 1977, 21). African Christianity is therefore an attempt by Africans to re-define Christianity into African thought-forms and idioms (Kurewa 1975, 36).

For most AICs, Easter celebrations denote the remembering of the Lord's suffering, his subsequent death, burial and resurrection. This was also the understanding of the early church. The early church was persecuted for believing that Jesus was the awaited Messiah and participating in the ritual of the Holy Eucharist (Comby 1985, 11). Though the church was persecuted, it continued to gather together for the liturgy of the word and of the sacrament, remembering the night Jesus suffered, died and was buried as well as his resurrection, on the third day (Comby 1985, 11). This is how Christians understand the meaning and origin of Easter celebrations. It is against this milieu that almost all Christian denominations acknowledge Easter celebrations with much reverence. Arguably, the Easter event 
(the commemoration of the death, burial and resurrection of Jesus Christ) is the heartbeat of Christian religion. Against this background, our study seeks to critically investigate the theological understanding of Easter, its meaning and significance by the Johane Masowe Chishanu yeNyenyedzi Church, a religious movement that is an off-shoot of the Johane Masowe Church in Zimbabwe. Furthermore, we intend to contextualise the movement's theology of memory within the wider paradigm of African Indigenous Churches' (AIC) theology.

\section{The centrality of commemorating the Easter event in the AIC's liturgical calendars}

The study observes that most African Indigenous Churches (AICs) observe the Easter commemorations and anniversaries. Furthermore, they observe church anniversaries in order to commemorate their humble beginnings as well as the triumphs and tribulations of their spiritual leaders. Examples abound among AICs. This is true in many Zimbabwean cases, such as the Zimbabwe Assemblies of God (Africa); Forward in Faith (ZAOGA FIF) of Archbishop Ezekiel Guti; the Zion Christian Church (ZCC) of Bishop Nehemiah Mutendi; and the African Apostolic Church (AAC) of Archbishop Paul Mwazha, among others. These churches observe church anniversaries annually. The researchers of this study argue that these anniversaries and celebrations are observed in order to keep the balance between orthodoxy and ortho-praxis among the entire membership of the churches. They are also observed in order for members to align the faith to the vision and faith of their spiritual leaders. For instance, ZAOGA FIF Church has its annual church anniversaries in the month of May, every year (Biri 2014, 63-78), while the ZCC holds the anniversary marking the founding of the Church by Samuel Mutendi at Defe Dopota, every July (Chimininge 2014, 38). Similarly, the AAC has its annual gathering at Guvambwa during the month of May (Ndlovu 2014, 49).

This study observes that these commemorations are in accordance with either remembering the birth pains of the Church, for instance ZOAGA FIF church was birthed in May 1960 under a gum tree in Bindura (Guti 1999, 1), or the celebration of the great work their spiritual leaders have accomplished. Similarly, members of the Zion Christian Church converge at Defe Dopota in Gokwe every July to remember the life and work of their spiritual leader (Samuel Mutendi) who died on 20 July 1976 and was buried at Defe Dopota in Gokwe (Chimininge 2014, 38). Apart from these churches commemorating the triumph of their church leaders and the beginning of their churches, they also commemorate Easter. 


\section{Historical background of the Johane Masowe Chishanu yeNyenyedzi Church}

This section observes that Johane Masowe Chishanu yeNyenyedzi is one of the many Johane Masowe Chishanu Churches in the Zimbabwean religious landscape. Today we have numerous Johane Masowe Chishanu Churches (John of the Wilderness Churches of the Friday), but with different identities such as: Johane Masowe Chishanu nguvo tsvuku (John of the Wilderness Church of Red Clothes); Johane Masowe Chishanu Mudzimu unoyera (John of the Wilderness Church of the Holy Ancestor); Johane Masowe Chishanu Vadzidzi (John of the Wilderness Church Disciples), to mention just a few. However, the original founder of all Masowe Churches was Shonhiwa Masedza, whose religious name was Johane Masowe. He founded this church in the 1930s in the then Rhodesia, now Zimbabwe (Mukonyora 2007, 18). After his death, Mudyiwa Dzangara took over the leadership of the Church until he died in 1989 (Engelke 2007, 45). In the 1990s Sandros founded another Johane Masowe Chishanu branch in Chitungwiza (Engelke 2007, 55). Sandros professed that he saw the star (Nyenyedzi) leading the Church during a prayer retreat at Nyatsime pool there in Chitungwiza (Engelke 2007, 55). However, the name Masowe yeNyenyedzi was popularised by the disciples of Sanders/Sandros in 1996 after Sanders had died. The disciples of Sandros who popularised the name Johane Masowe Chishanu yeNyenyedzi were, namely, Baba Anthony Kanengoni and Baba Tawanda Ndaidza; both from the Midlands province. The disciples who were fighting over leadership succession were Baba Micho, Baba Nzira and Baba Wimbo (Interview 7: Baba Gilbert Samaita 4 April 2015). This is how Johane Masowe Chishanu Vadzidzi led by Micho, led by Wimbo and the original Johane Masowe Chishanu remained under the leadership of Baba Nzira (Interview 4: Madzibaba Andria 4 April 2015). The fourth one is the Johane Masowe Chishanu yeNyenyedzi led by Anthony Kanengoni. Though it is a break-away movement from the main Johane Masowe Chishanu, this church continued to revere the leadership and doctrine of Johane, Emanuere and Sandros. It is against this background that this study seeks to discuss how Johane Masowe Chishanu celebrates the triumph of these three church fathers, Johane, Emanuere and Sanders during Easter celebrations.

\section{Easter celebrations in Masowe yeNyenyedzi in Zimbabwe}

The Johane Masowe Chishanu yeNyenyedzi Religious Movement in Zimbabwe commemorates Easter with a difference. This study noted that their gathering on Easter dates is not a coincidence, but rather planned to commemorate Easter together with other Christian denominations. Actually the event is also called Easter celebration or the Passover feast in this religious movement. The word 'Easter' is common among the members of the Johane Masowe Chishanu yeNyenyedzi Church, as it is common to other church organisations in Zimbabwe. During 
Easter, the Johane Masowe Chishanu yeNyenyedzi Church starts congregating on Thursday around 15:00. According to the interviews 15:00 is significant for them because they believe that this is the time mwanakomana we mhiri yegungwa akatanga kutambudzwa (the time when the Son of Man was taken into the hands of persecutors) (Interview 9: Madzibaba Morris 4 April 2015). In their semantics 15:00 is called nguva ye kutambudzwa kwe mwanakomana mhiri yegungwa (the hour of the suffering of the Son of Man overseas). Therefore the following paragraph showcases the nexus between Johane Masowe Chishanu yeNyenyedzi Church in celebrating Easter with other Christian denominations world-wide. However, later in this study the researchers will showcase the differences between the Johane Masowe Chishanu yeNyenyedzi Church celebrations of Easter and those of other Christian denominations the world over.

\section{Similarities between the celebrations of Easter in the Masowe yeNyenyedzi Church in Zimbabwe, and those of other religious groups}

\section{Religious fasting}

The study observes that this religious group practises fasting during Easter commemorations. Fasting refers to abstaining from some kinds of food or drink for religious observance. Likewise, the Johane Masowe Chishanu yeNyenyedzi Church members do not bath or eat meat during Easter celebrations. Their fasting starts from 15:00 on holy Thursday till 15:00 the following day. The study posits that there is a nexus between what this religious group does to remember the suffering of Jesus Christ, with what other Christian denominations do, for example the Roman Catholics. Though this religious group goes to the extremes of not bathing, the Catholics also do not eat meat on the holy Friday. The concept behind not bathing and abstaining from eating meat for this religious movement is that they are sharing their sorrows with the mother of Jesus. In their semantic they say tirikubatidza amai Maria kuchema mwanakomana wavo wakabaiwa mhiri yegungwa (we are mourning together with Mary the mother of Jesus) (Interview 10: Baba James Bhasera 4 April 2015). Therefore, for the Johane Masowe Chishanu yeNyenyedzi Church, every Thursday 15:00 to Friday 15:00 is a mini Easter. They don't eat meat from 15:00 on Thursdays till 15:00 on Fridays. The study also observes that during funerals all members of the Masowe Chishanu Churches do not eat meat. Still on fasting, the Johane Masowe Chishanu yeNyenyedzi Church members do not eat leavened bread throughout the whole Easter weekend. This is a practice also found among other indigenous churches such as the ZCC, namely that during Easter celebrations they don’t eat leavened bread (Interview 6: Musoni Charity 29 June 2015). 


\section{Evidence of the passion narratives}

This study posits that there is also vivid evidence of the Johane Masowe Chishanu yeNyenyedzi Church commemorating the suffering and death of Jesus Christ. This study argues that the Johane Masowe Chishanu yeNyenyedzi Religious Movement appropriates Jesus' death as a historical event. Like in any other Christian movement, the passion narratives of Jesus are intense in this religious movement. This is evidenced by their teaching nguva dzenhatu dzekutambudzwa kwe mawanakomana mhiri yegungwa (15:00 as the time the Son of Man was executed). Therefore, it is not by chance that the Johane Masowe Chishanu yeNyenyedzi Church congregates during Easter, following the Christian calendar. Most prominently on the passion narratives is the practice called pachoto (men sitting around fire on Thursday night, their first night of Easter celebrations). Choto is a Shona word which can literally be translated to mean fireplace. However, pachoto for this religious movement denotes men sitting around the fire the whole night, discussing many topics. Among the topics are marriage and old people called vasadare (Older in Marriage) giving counselling to the married young. The study noted that the concept of Choto is a borrowed phenomenon from two different worldviews. Firstly, it is from the Roman Catholic background where they talk of moto wa Peter (the Fire of Peter), resembling the night Peter denied Jesus three times according to the biblical narratives (Mark 14:72). Thus on that note men of the Johane Masowe Chishanu Church sit around the fire from 21:00 till 03:00 the next morning. Secondly, men who are sitting around the fire is a concept borrowed from African culture. In Shona culture this pachoto is called padare, from where the term vasadare derived in the Johane Masowe Chishanu yeNyenyedzi Church semantics. Thus during padare, young men are taught how to propose to a girl and the young in marriage are taught how to love their wives.

\section{Christian symbols}

The cross is one of the earliest and most widely used Christian symbols. In its broad sense the cross symbolises the death of Jesus (Comby 1985, 11). This study observed that the Johane Masowe Chishanu yeNyenyedzi Church members have symbols of the cross on their religious clothes. This religious movement also imitates the cross sign when opening the prayer and in closing the prayer. Therefore, above similarities posit that this religious movement also believes that Jesus died on the cross. This is how the Johane Masowe Chishanu yeNyenyedzi Church celebration of Easter relates with other Christian denominations' understanding the significance of Easter.

On the other hand, this study also observed a number of disparities between the Johane Masowe Chishanu yeNyenyedzi Church celebrations of Easter and those of other religious groups in Zimbabwe. Thus the following section discusses the differences between the Johane Masowe Chishanu yeNyenyedzi Church celebrations of Easter and those of other Christian denominations. 


\section{Differences between the Masowe yeNyenyedzi Church celebrations of Easter in Zimbabwe, and those of other religious groups}

\section{Tsoro ya Johane (literal meaning - relay of three leaders)}

The celebration of Easter in the Johane Masowe Chishanu yeNyenyedzi Church starts with Tsoro ya Johane (a religious name). According to our informants tsoro ya Johane simply means a reflection on the salvific work of the three church fathers: Shonhiwa, Mudyiwa and Sanders successively. This is a narration on how God used these church fathers to start and develop an African Indigenous Church (AIC). Therefore tsoro ya Johane doctrine of the Johane Masowe Chishanu yeNyenyedzi Church is a memorial service for their church fathers. These include Johane, Emanuere and Nyenyedzi, who are to them sacred leaders. In the interview our informant argues that the work done by John the Baptist and Jesus Christ is parallel to the work done by Shonhiwa (Johane), Mudyiwa (Emanuere) and Sanders (Nyenyedzi) for the salvation of Africans in Africa. Masowe yeNyenyedzi believes that since it was mhiri yegungwa (overseas) where God sent John the Baptist, it is indeed the same God who sent Shonhiwa (Johane) first, an African to preach to Africans repentant from witchcraft, ancestor worship, brewing of beer, and smoking, among others things. After him came Mudyiwa (Emanuere) who introduced gumi remitemo, miko ne mirairo (Ten Commandments, dietary laws and church regulations). Lastly, God sent Sanders/Sandros (Nyenyedzi) who introduced munamato wegore (annual prayer), musangano wegore/ kuverengwa ne Nyenyedzi (annual conference/star census), and jorodhani/zambuko rinoera (sacred water baptism).

Consequently Tsoro ya Johane therefore is figurative of an old traditional game called tsoro ye mutatu, literally referring to a game of three small stones. The game is played in turns but using three stones. In this sense tsoro denotes the role that these three key spiritual leaders (Shonhiwa, Mudyiwa and Sanders) played in the growth and development of the Masowe yeNyenyedzi Religious Movement in Zimbabwe. Again a song was composed to celebrate the triumphal victory of these spiritual leaders: Johane, Emanuere and Nyenyedzi.

Kwakatanga Baba Johane (There came Johane).

Ndokuzouya Emanuero (After him Emanuere).

Kwakazouya Nyenyedzi (Lastly came the star).

Denga rose raombera (The heavens burst forth in jubilation).

This study opines that the term mhiri yegungwa (overseas) is used metaphorically. Mhiri yegungwa is commonly used in the Johane Masowe Chishanu yeNyenyedzi Church, and it denotes epistemological, theological and racial divides. In summary, for the Johane Masowe Chishanu yeNyenyedz Church, revelation cannot cross racial and cultural boundaries. Mhiri yegungwa in its usage signifies epistemological, 
theological and racial divides in the sense that for the Masowe yeNyenyedzi Religious Movement, God deals with people within their social, psychological and cultural settings. Their argument is that there is no way God would send a white Jesus to serve a black community. This postulates that Jesus Christ was sent to the people of overseas, Jesu we mhiri yegungwa (Jesus of and for overseas).

Further, the Johane Masowe Chishanu Church argues that Africans have their own sins such as witchcraft, sorcery and ancestor cultic worship, which are different from the sins of whites (Interview 8: Mudzidzi Roswensy Nhanga 10 April 2015). For Masowe yeNyenyedzi, the myriad of differences in worldviews between Europeans and Africans underpin God's design to send Johane, Emanuere, and Nyenyedzi (all Africans) to Africans. Thus this study observes that even though the death of Jesus was accepted by the Johane Masowe Chishanu yeNyenyedzi Church as a historical fact, it has no relevance for the salvation of Africans according to this religious movement.

This is how the Johane Masowe Chishanu yeNyenyedzi Religious Movement deviates from central Christian spiritual elements such as faith in Jesus Christ for salvation of human kind. Salvation in this religious movement did not come because Jesus died on the cross. Salvation in Masowe yeNyenyedzi came to Africans through the salvific work of Johane, Emanuere and Nyenyedzi. For them, all other denominations are lost and there shall be a time in future that all Africans will be white garmented believers, according to Baba James in an interview (Interview 5: Madzibaba James 17 October 2014).

This study posits that the importance and significance of Jesus Christ's salvific work is being replaced by Johane, Emanuere and Nyenyedzi in the Johane Masowe Chishanu yeNyenyedzi Church in Zimbabwe. This is an indication of the emergence of a 'theology of displacement'. In this study 'theology of displacement' denotes a religious movement eliminating certain spiritual elements of an adopted religion and replacing them with other spiritual elements. The study also posits that this 'theology of displacement' in the Johane Masowe Chishanu yeNyenyedzi Church was influenced by the members' African worldviews. According to Banana (1991, 27), Africans believe that an ancestral spirit continued to act as a mediator between God and the living human beings.

It is against this milieu that the elderly people of the Johane Masowe Chishanu yeNyenyedzi Church are given turns to narrate the life history of Johane, Emanuere and Nyenyedzi during Easter commemorations in Zimbabwe. The study theorises that Masowe spirituality revolves around mutumbi mitatu 'Johane, Emanuere and Nyenyedzi' (Interview 11: Madzimai Melisa Gambiza 2 April 2015). In the narration, the emphasis will be Mwari wakatuma Johane, Emanuere, Nyenyedzi ku ndunzi yo mutema kuti igowanikwa ichibva mukupira mudzimu ne mashave (God sent Johane, Emanuere and Nyenyedzi to black Africans so that they will be redeemed from worshipping ancestors) (Interview 9: Madzibaba Morris 4 April 2015). Therefore, 
in the Johane Masowe Chishanu yeNyenyedzi Church, teaching the doctrine of the second coming of Jesus Christ (Parousia) to judge the world of sinners is trivial.

For the Johane Masowe Chishanu yeNyenyedzi Religious Movement Jesus did not die for the sins of Africans (Interview 8: Mudzidzi Roswensy Nhanga 10 April 2015). For them, God's original plan was to serve Jews and whites first by sending John the Baptist and Jesus Christ. However, the whites denied the word of God by killing both John the Baptist and Jesus Christ. Hence God condemned the whites (Interview 3: Madzibaba Amos Machetu 4 April 2015). For the Johane Masowe Chishanu yeNyenyedzi Religious Movement this explains how God turned his back against the whites and sent his word to Africans through Masedza, Mudyiwa and Sandros. It is against this knowledge that the Johane Masowe Chishanu yeNyenyedzi's statement of confession reads: 'Tinotenda mitumbi mitatu, Baba Johane, Baba Emanuere ne Nyenyedzi' (we believe in three scared bodies, i.e., Johane, Emanuere and Nyenyedzi) (Interview 12: Madzimai Tsitsi 2 April 2015). The doctrine of tsoro yaJohane is re-enacted by songs in this religious movement. Below is another song composed and dedicated to the remembrance of Johane Masowe Chishanu yeNyenyedzi spiritual church leaders.

Baba Johani tiyerese tivanamate (Father John, sanctify us so that we can worship Him).

Baba Johane vana venyu vaungana (Father John, your Children have come).

Emanuero vana venyu vaungana (Emanuel, your children have come).

Tauya Nyenyedzi tiyerese taungana (We have come, Star, sanctify us).

This study perceives that the Johane Masowe Chishanu yeNyenyedzi Church does not preach anything else except the message and doctrine of Johane Masowe, Emanuere and Nyenyedzi. Perhaps it is because Johane Masowe, the founder, did not preach about salvation through Jesus Christ to his congregants, but emphasised the discontinuity of Western Christianity evidenced by disregarding the Bible as central to the new faith. It is against this backdrop that critics of the movement argued that Johane Masowe as the prophet, to whom God revealed the truth, did not even tell his followers about Jesus' salvific power which saves humanity from all social ills, suggesting that he (Johane) sees himself as a messianic figure to Africans while Jesus was a messianic figure to the Jews (Gifford 2009, 94). In this regard Gifford further argues that Johane Masowe Churches represent an amorphous gospel, the gospel that Jesus was the one sent to the Israelites while Johane Masowe was sent to black Africans (Gifford 2009, 94). Amanze also wrote that Johane told his followers that Jesus came for the Jews (Amanze 1998, 82) and he (Johane) was sent for black Africans. This is how Johane deviates from being an authentic Christian church to a syncretistic religious movement in Zimbabwe.

On the other hand, the study posits that African Indigenous Churches (AICs) have accepted the divinity of Jesus. Amanze, who did an extensive study on AICs in Botswana, observes that almost all African churches celebrate Good Friday and 
Easter triumphantly as the time when Jesus the Christus victor neutralised evil spirits such as witchcraft, jealousies, diseases and evil powers, disgruntled ancestors, and many others that deny human beings the fullness of life (Amanze 1998, 107). In a contrasting view, the Johane Masowe Chishanu yeNyenyedzi Church does not accept that Jesus Christ neutralised evil spirits such as witchcraft, sorcery, diseases and evil powers. Though the Johane Masowe Chishanu yeNyenyedzi Church observes Easter dates and congregates from Thursday around 15:00 till Sunday, they hardly preach about Jesus Christ's death, burial and resurrection. Instead, they only preach about how their Church started and the triumphs of their three spiritual leaders; Shonhiwa (Johane), Mudyiwa (Emanuere) and Sanders (Nyenyedzi).

In most of the interviews and participant observation carried out in the Johane Masowe Chishanu yeNyenyedzi Church, the researchers of this study observed that prayers are not made in the name of Jesus. The study posits that the image of Jesus in this Church has been overshadowed by their spiritual leaders. It is in this regard that scholars argued that Johane Masowe is equated to Jesus Christ who was crucified overseas. The researchers of this paper are compelled to posit that the salvific and atoning work of Jesus Christ has been substituted by the three African spiritual leaders in the Johane Masowe Chishanu yeNyenyedzi Church of today. The Johane Masowe Chishanu yeNyenyedzi Church understands that salvation was made possible through the work of their three spiritual leaders (Johane, Emanuere, Nyenyedzi), hence they revere them.

For Reese, the Johane Masowe adherents came to conclude that Johane was more than just a prophet (Reese 2008). For him the Masowe Church has created a website of the Gospel of God Church in Nairobi, which contains stylish arguments to support the idea that Johane Masowe can be equated to the work that Jesus was sent for by God to the Jews (Reese 2008). Masowe Churches argue that Jesus' ministry was limited to the 'lost sheep of Israel' (Matthew 15:24) and so could not have fulfilled the prophecy of Isaiah 19:20 that a Saviour would come to rescue those oppressed in Egypt (Reese 1995, 1-12). From the interviews it was made clear that Johane came and was prophesied by a traditional medium spirit, that he was the awaited messiah who will serve Africans from evil spirits (Interview 2: Madzibaba Andrea Mucheto 23 April 2015). Therefore, after tsoro ya Johane another discontinuity in the Johane Masowe Chishanu yeNyenyedzi Church's commemoration of Easter, is that the Bible has been replaced by tsanangudzo dzemweya (the sayings of the spirit).

\section{Tsanangudzo dzemweya (sayings of the spirit)}

The term tsanangudzo dzemweya refers to what the spirit said before and what the spirit is still saying today in the Johane Masowe Chishanu yeNyenyedzi Religious Movement in Zimbabwe. During Easter celebration, Friday will be the day of tsanangudzo dzemweya (narration of what the spirit had already said). This study noted that there is a group of young educated men and women who are busy putting 
up together tsanangudzo dzemweya. These sacred sayings of the spirit constitute the sacred scripture for the Johane Masowe Chishanu yeNyenyedzi Church in Zimbabwe. The argument raised is that the Bible is a book for Jews (Interview 3: Madzibaba Amos Machetu 4 April 2015). Again the Johane Masowe Chishanu yeNyenyedzi Church believes in the 'theology of discontinuity'. By 'theology of discontinuity' this study posits that Masowe Chishanu yeNyenyedzi's theological position is that; what happened in the ancient near East has no relevance to the salvation of Africans. People of overseas were guided by the sayings of the then prophets and spiritual leaders. These sayings were later compiled together to form what is referred to today as the Bible (Interview: Baba Amos 17 May 2014). Likewise, the Johane Masowe Chishanu yeNyenyedzi Church believes in the 'live and direct' (Engelke 2007, 55) communication with God. It is these sayings of the spirit during prayer meetings that become the source of their theology. Therefore, the group of educated young people are given turns to read out what they have compiled together from time past to time present and the elderly people will be asked to give comment on what was gathered. Asking a close friend on how one can have access to the sacred writings, his response was: '.. the books are kept very secretly to prevent the enemies of the religion who will want to destroy the evidence of the work of the spirit in Africa' (Interview 1: A member who wants to remain anonymous 4 April 2015). Though our informant did not disclose who the enemies of this religion were, arguably whites are regarded as enemies of this religion. For Madzimai Melisa, whites are not allowed to join this religious movement (Interview 11: Madzimai Melisa). This is so because whites are being accused of bringing the Bible which they (whites) used to manipulate Africans and later colonised Africa (Interview 11: Madzimai Melisa 2 April 2015). Melisa professed that mweya wakati musabate muchena/murungu pamusoro (the Spirit said 'don't convert a white person') (Interview 11: Madzimai Melisa 2 April 2015). Therefore, from what Madzimai Melisa raised in an interview, it is imperative to conclude that whites are regarded as the enemies of this religious movement in Zimbabwe. This study observes that the Johane Masowe Chishanu ye Nyenyedzi Church does not accommodate whites even in countries where whites are the majority population. The study noted that there is a branch of the Johane Masowe Chishanu Church in the United Kingdom, but all members are black Africans.

During Easter commemorations emphasis is placed on kuchengeta tsika dze vanhu vatema (observing African culture). During Easter celebration, it was mentioned that mweya wakafarira tsika dze vanhu vatema (the spirit admired African culture). Therefore, all women should respect men according to African culture. Kneeling down for women when greeting male counterparts is part of the Johane Masowe Chishanu yeNyenyedzi Church; an adoption from African traditional culture. This is how traditional utensils such as mbiya (small clay pot) feature prominently on the Masowe yeNyenyedzi kirawa (holy place/altar). Mbiya is used to contain sacred stones and holy water for religious rituals. Likewise mbiya is used during African 
traditional rituals such as lobola, traditional rain ceremonies (bira remvura) and many other functions.

\section{Gumi re mitemo (Ten Commandments)}

After tsanangudzo dzemweya, on a Saturday, the Johane Masowe Chishanu yeNyenyedzi Church teaches its members the importance and significance of gumi re mitemo (the Ten Commandments). Gumi re mitemo refer to central rules and regulations that shape the spirituality of the Johane Masowe Chishanu yeNyenyedzi Religious Movement in Zimbabwe. The study observes that though this religious movement claims to be Christian (although they do not read the Bible), some of the Commandments resemble the Old Testament biblical Commandments (Exodus 20:1-17). During Easter commemorations, special emphasis was given to one of their Commandments, 'honour your father and your mother so that your days may be added' (Kudza Baba na Mai vako kuti mazuva okurarama awedzerwepanyika). This Commandment is also found in the Bible (Exodus 20:5). Commenting on this similarity, Baba Morris posits that 'the same God who revealed this Commandment to Moses of the Bible, is the same God who reveals this Commandment to Emanuere' (Interview 9: Madzibaba Morris 4 April 2015). However, it is of great interest to note that during Easter celebrations only one Commandment 'honour your father and mother...' is the key message the whole Saturday during the celebrations. Members are given the opportunity to ask God for forgiveness, particularly those who have wronged their parents and fasting days will be proclaimed for the forgiveness of their sins. For this religious movement one's parents are small gods who can plead with God for one to have more years on earth (Interview 9: Madzibaba Morris 4 April 2015). Therefore, the above section has discussed how the Johane Masowe Chishanu yeNyenyedzi Church diverges from the central spiritual elements, evidenced by how they celebrate Easter in Zimbabwe.

\section{Conclusion}

This study has observed that the Johane Masowe Chishanu yeNyenyedzi Religious Movement celebrates Easter with a difference. It has been realised that the Johane Masowe Chishanu ye Nyenyedzi Church celebrates the triumphs of Johane, Emanuere and Nyenyedzi during Easter celebrations in Zimbabwe. The abovementioned three legendary religious figures are venerated and given due respect, particularly during Easter celebrations. Tsoro ya Johane is very central in shaping the theology of the Johane Masowe Chishanu yeNyenyedzi Church in Zimbabwe. Although the timing of the veneration rituals discussed above falls within the Easter-tide, there is no gainsaying that they accord messianic status to Johane Masowe, Emanuweri and Sandros and emphasise re-incarnation over bodily resurrection. It is against this milieu that we conclude that the Johane Masowe Chishanu yeNyenyedzi Church has 
deviated from the central Christian spiritual tenets and practice in a myriad of ways. We thus posit that the Johane Masowe Chishanu yeNyenyedzi Religious Movement has gravitated more towards becoming a syncretistic movement for a number of reasons. Firstly, it has replaced the centrality of Jesus with the commemoration of its leaders. Secondly, it has replaced the centrality of the Bible by introducing tsanangudzo dze mweya. Thirdly, it has presented a theology that is exclusively black African, where other nationalities living in other continents (mhiri) are excluded from the economy of salvation. Fourthly, it has denied the bodily resurrection of Jesus and his second coming to judge the universe. It is this messianic deification of Johane, Emanuere and Nyenyedzi, among others, that has led the Johane Masowe Chishanu yeNyenyedzi Religious Movement to become a syncretistic, fundamentalist religious movement in Zimbabwe.

\section{References}

Amanze, J. 1998. African Christianity in Botswana. Gweru: Mambo Press.

Banana, C. 1991. Come and share: An introduction to Christian theology. Gweru: Mambo Press.

Biri, K. 2014. 'Sacred Sites in an African indigenous church in Zimbabwe: A critique of Zaoga Fif.' In Multiplying in the Spirit: Africa initiated churches in Zimbabwe, E. Chitando, M.R. Gunda and J. Kügler (eds), 63-78. Bamberg: University of Bamberg Press.

Chimininge, V. 2014. 'Zion Christian Church.' In Multiplying in the Spirit: Africa initiated churches in Zimbabwe, E. Chitando, M.R. Gunda and J. Kügler (eds), 33-48. Bamberg: University of Bamberg Press.

Comby, J. 1985. How to read church history: From the beginning to the fifteenth century, 1st edition. London: SCM Press.

Engelke, M. 2007. A problem of presence: Beyond Scripture in an African church. Berkeley: University of California Press.

Gifford, P. 2009. Christianity, politics and public life in Kenya. London: C. Hurst.

Guti, E. 1999. History of ZOAGA Forward in Faith: The book of Remembrance, how it began and where it is going. Harare: EGEA Publication.

Kurewa, J. 1975. 'The meaning of African Theology.' Journal of African Theology for Southern Africa 11(2): 32-42.

Mukonyora, I.M. 2007. Wondering a gendered wilderness: Suffering and healing in an African initiated church. New York: Peter Lang.

Ndlovu, L. 2014. 'The African Apostolic Church led by Paul Mwazha as a response to secularization.' In Multiplying in the Spirit: Africa initiated churches in Zimbabwe, E. Chitando, M.R. Gunda and J. Kügler (eds), 49-62. Bamberg: University of Bamberg Press.

Reese, R. 1995. Lessions in mission from an African initiated church: A case study of the Zimbabwean VaPostori of Johane Masowe. Online, pp.1-12. Available at: <www.jimmission.org.uk/.../reese-african.> (accessed 20 March 2015).

Reese, R. 2008. Dictionary of African Christian biography: Johane Masowe Gospel of God Church (1914-1973). Online. Available at: <www.dacb.org/stories/zimbabwe/johane_masowe.html (accessed 18 March 2015). 
Shorter, A. 1977. African Christian theology: Adaptation or incarnation? New York: Orbis.

Sundkler, B.C.S. 2000. The history of the church in Africa. Cambridge: Cambridge University Press.

\section{Interviews}

Anonymous: 4 April 2015. Tsoro ya Johane a reflection of the salvific work of Johane, Emanuere and Sanders, lower Gweru, Midlands.

Madzibaba (i.e. title for adult male member) Andrea Mucheto: 23 April 2015. The teaching about Tsoro yaJohane, age 65 at Lower Gweru Midlands.

Madzibaba Amos Machetu: 4 April 2015. Jesus and the Bible are central features in European churches, Lower Gweru, Midlands.

Madzibaba Andria: 4 April 2015. Defe, Gokwe, Midlands Province.

Madzibaba James: 17 October 2014. Defe, Gokwe, Midlands Province.

Musoni Charity: 29 June 2015. Abstaining from eating unleavened bread during Easter in the ZCC, Berejena, Chivi District, Masvingo.

Baba Gilbert Samaita: 4 April 2015. Mutumbi mitatu yaka shandiswa ne mweya Lower Gweru, Midlands.

Mudzidzi (i.e. neophyte) Roswensy Nhanga: 10 April, 2015. Easter celebrations in Johane Masowe Chishanu Vadzidzi, at Madziva police camp Mashonaland central.

Madzibaba Morris, M: 4 April 2015. Masowe Enyenyedzi member, Lower Gweru, Midlands.

Baba James Bhasera: 4 April 2015. The splitting of Johanne Masowe into many Masowe Churches after the death of Johane, Lower Gweru, Midlands.

Madzimai Melisa Gambiza: 2 April 2015. Masowe believes in three sacred bodies (mitumbi mitatu) sent by God to Africans, Lower Gweru, Midlands.

Madzimai Tsitsi M: 2 April 2015. A prophetess in Masowe Enyenyedzi, Lower Gweru, Midlands. 